\title{
A case of epigastric heteropagus twinning with other congenital abnormalities in a Chihuahua puppy
}

\author{
Een asymmetrisch dubbelmonster geassocieerd met andere congenitale \\ afwijkingen bij een chihuahuapup
}

\author{
${ }^{1} \mathrm{~J}$. House, ${ }^{2}$ K.R. Barrand, ${ }^{3}$ P. Cornillie \\ ${ }^{1}$ The Queen's Veterinary School Hospital, University of Cambridge, Madingley Road, Cambridge, CB3 \\ OES, United Kingdom \\ ${ }^{2}$ Fenwold Veterinary Practice Ltd, Heath Road, Skegness, Lincs, PE25 3ST, United Kingdom \\ ${ }^{3}$ Department of Morphology, Faculty of Veterinary Medicine, Ghent University, Salisburylaan 133 , \\ 9820 Merelbeke, Belgium
}

keithbarrand@msn.com

\begin{abstract}
A two-year-old Chihuahua was presented on day 58 of pregnancy due to very marked abdominal distension. A cesarean section was performed and five normal and one clearly abnormal puppy were delivered. Examination of the abnormal puppy revealed a combination of congenital anomalies including epigastric heteropagus twinning. The autosite showed focal cranial aplasia cutis, anasarca, lissencephaly, palatoschisis, sternal agenesis and eventeratio (gastroschisis/schistocoelia). The partly formed parasitic twin was attached at the sternal region of the autosite and demonstrated four formed limbs, atresia rectum, atresia ani, a single kidney, tail agenesis and atresia vulvae. To the authors' knowledge, this is only the third reported case of heteropagus conjoined twinning in the dog and the first reported case of canine epigastric heteropagus twinning. In addition, there appear to be no reports in the veterinary literature noting an association with conjoined twinning in the dog with focal cranial aplasia cutis, eventeratio, lissencephaly, palatoschisis and anasarca. An in-depth literature review was hampered by the lack of a uniform nomenclature to identify this type of conjoined twinning.
\end{abstract}

\section{SAMENVATTING}

Een twee jaar oude chihuahua met duidelijk opgezet abdomen werd op 58 dagen dracht via een electieve keizersnede verlost van vijf normale en één duidelijk afwijkende pup. De misvormde pup was een asymmetrisch dubbelmonster waarbij de parasiet in het navelgebied met de autosiet verbonden was. De autosiet vertoonde aplasia cutis ter hoogte van het schedeldak, anasarca, lissencefalie, palatoschisis, sternale agenesie en eventeratio (gastroschisis/schistocoelia). De parasiet was slechts gedeeltelijk aangelegd en was ventraal ter hoogte van de thorax van de autosiet vastgehecht. De parasiet was samengesteld uit vier ledematen, terwijl kop en staart afwezig waren. Atresie van de anus en vulva werd opgemerkt. Inwendig werd slechts één enkele nier bij de parasiet aangetroffen. Voor zover de literatuur kon geraadpleegd worden, is deze casuïstiek slechts het derde uitvoerig beschreven geval van heteropagus bij de hond, waarbij de geassocieerde afwijkingen dit specifieke geval uniek maken. Een grondige literatuurstudie werd evenwel bemoeilijkt door het ontbreken van een uniforme nomenclatuur om een dergelijke vorm van dubbelmonsters te identificeren.

\section{INTRODUCTION}

The incidence of conjoined twinning in the dog is unknown but the paucity of reported cases in the literature suggests that it is very rare. The incidence in humans is $1: 50,000$ to $1: 100,000$ births (Hwang et al., 1996), which is the species believed to have the highest incidence (Tovar, 2009). The anomaly is caused by the incomplete splitting of the embryonic axis (Tovar, 2009). Conjoined twins may be symmetrical (Gemini symmetrica) or asymmetrical (Gemini asymmetrica) (N.E.V., 2006; Tovar, 2009).
Asymmetric or parasitic conjoined twins, consisting of an incomplete twin (parasite) attached to the body of a fully-developed twin (autosite), are rarer in man than symmetrical conjoined twins accounting for just $10 \%$ of all conjoined twins (Gupta et al., 2001). The term heteropagus twinning to describe asymmetric conjoined twins was coined by Potter and Craig (1975). Conjoined twins are further classified according to the most prominent site of conjunction (Tovar, 2009). Thus, the term epigastric heteropagus twinning refers to asymmetric twins in which the parasite is attached to the autosite at the epigastrium or cranial and 


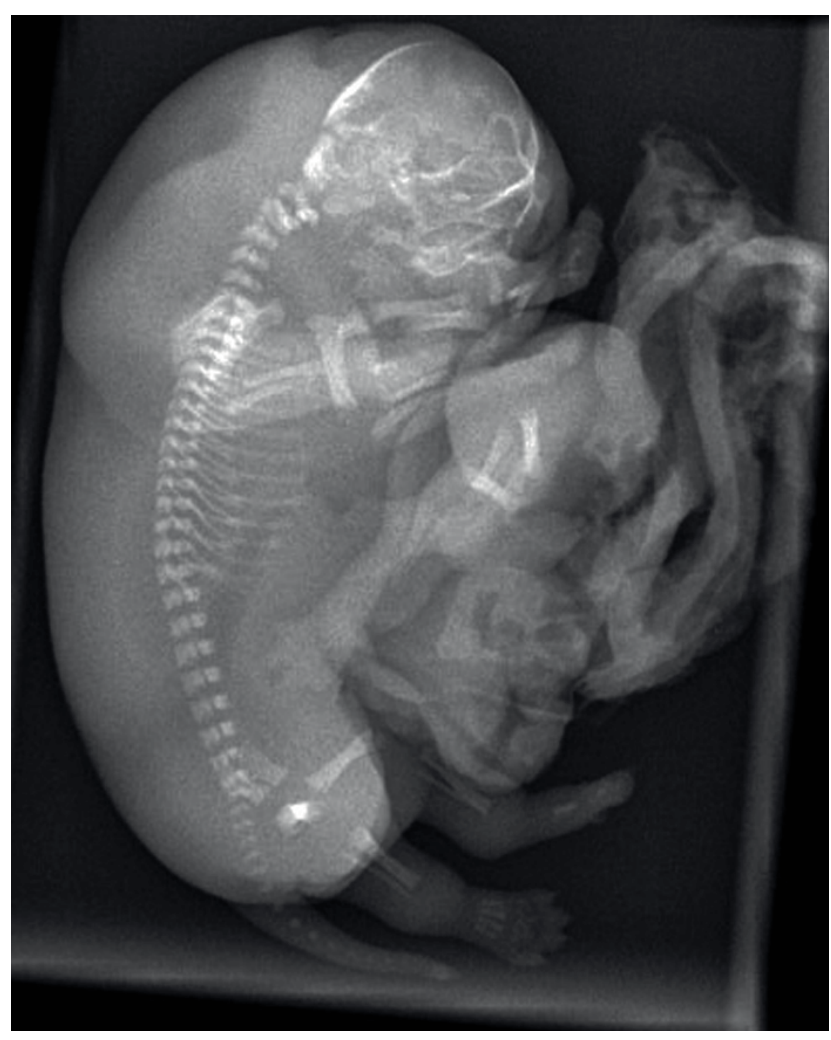

Figure 1. Lateral radiograph of the twins with the autosite on the left and the parasite on the right. The parasite has no visible vertebral column.

middle angle of the abdomen located within the sternal angle (Blood and Studdert, 1999). Classification and terminology are listed in Table 1.

Epigastric heteropagus twinning is a rare type of conjoined twinning, of which a review of the literature revealed only 37 reported cases in humans, in single cases case series (Saha and Dewan, 1995; Karnak et al., 1999; Ozcan et al., 2000; Cury and Schraibman 2001; Ribeiro et al., 2005; Kanamori et al., 2006) and two case reviews (Tongsin et al., 2003; Bhansali et al., 2005).

The etiology of conjoined twinning is believed to be related to incomplete separation of the embryo at approximately two weeks of gestation (in humans) and it is thought that they originate from a single blastocyst and represent a form of monozygotic twinning rather than fusion of dizygotic twins (Spencer, 1992).

Of 28 human cases reviewed in 2005 , five underwent DNA analysis and 4/5 were determined to be monozygotic (Bhansali et al., 2005). In one case of heteropagus twinning, dizygosity was seen and the possibility of early fusion of dyzygotic twins with partial resorption of the parasitic twin resulting in heteropagus conjoined twins was proposed (Logrono et al., 1997). However, it is also thought that epigastric heteropagus conjoined twins may result from ischemic atrophy of one part of a conjoined twin early in the gestational life (Charda et al., 1993).

There are two previous reports of conjoined twinning in the dog. Mazullo et al. (2007) described a case of incomplete caudal duplication in a puppy and Nottidge et al. (2007) described a case of monocephalus thoracophagus tetrabrachius in a dog. Other domestic species in which conjoined twinning has been reported include cattle (Arthur, 1956; Seebaransingh et al., 2007), sheep (Dennis, 1975), goats (Otiangi-Owitis et al., 1997), pigs (McManus et al., 1994; Selby et al., 1972), cats (Seavers, 2009) and guinea pigs (Hong et al., 1977). Non-domestic animals in which conjoined twinning has been reported include the black rat (Rattus rattus) and the European hedgehog (Erinaceus europaeus) (Kompanje, 2005).

\section{CASE HISTORY}

A live, female Chihuahua conjoined twin was delivered by elective cesarean section on day 58 of pregnancy along with five other grossly normal puppies. The conjoined twins were euthanized shortly after birth due to gross deformities.

\section{Radiography}

Conventional radiography demonstrated soft tissue fusion between the parasite and autosite. The absence of any part of a vertebral column in the parasite was remarkable (Figure 1).

\section{Necropsy}

The puppy was preserved in $10 \%$ formal saline and necropsy was performed. Gross examination of the

Table 1. Classification of heteropagus epigastric twinning according to the Nomina Embryologica Veterinaria (synonyms are given in square brackets) (based on N.E.V., 2006).

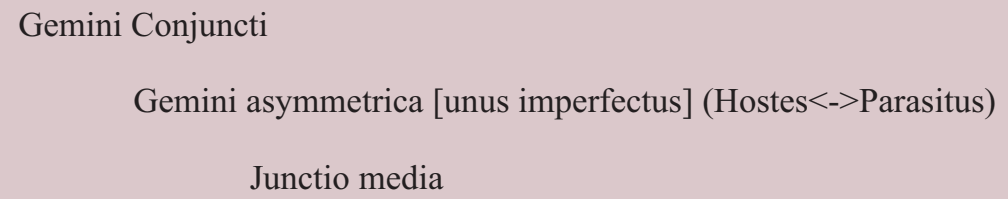

Anasarca (syn. Hydrops foetalis) refers to generalized, congenital oedema.

Eventeratio (syn. gastroschisis, schistocoelia, schistocoelia) refers to a congential fissure in the ventral abdominal wall, which allows the abdominal contents to protrude. 

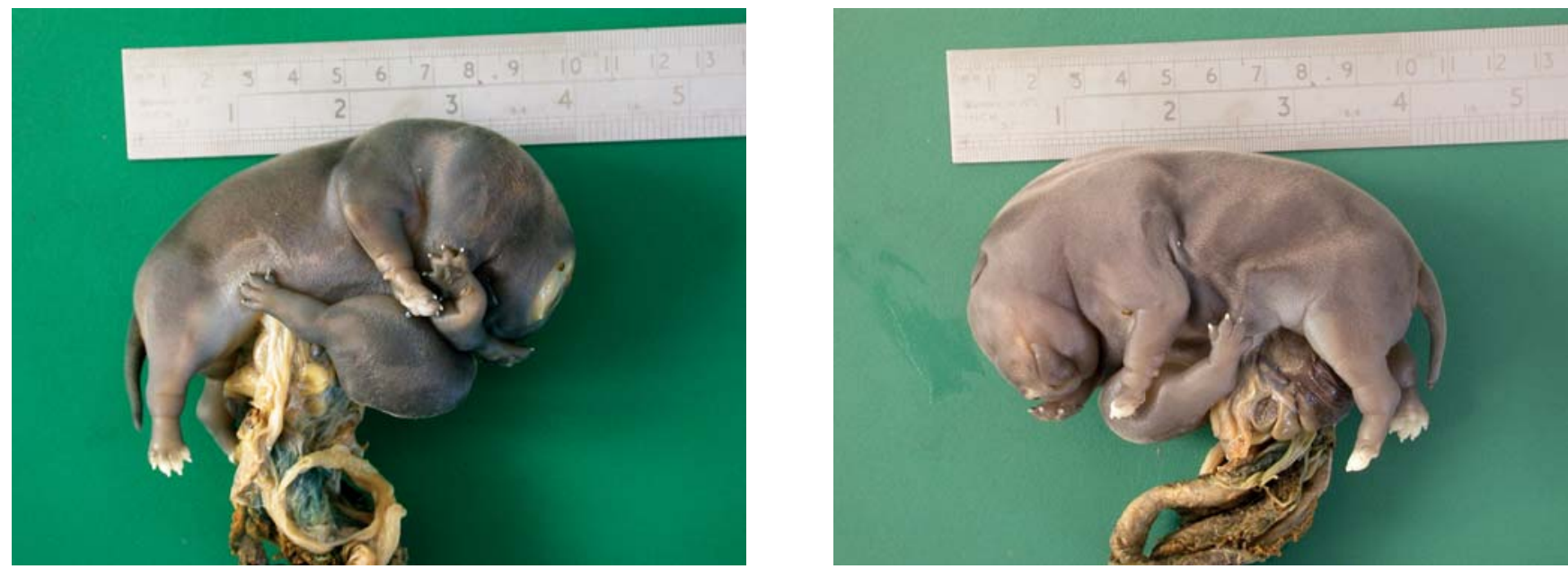

Figures 2 and 3. External appearance of the conjoined twins (after preserving in 10\% formalin solution).

conjoined twins revealed a combination of congenital anomalies including epigastric heteropagus twinning (Figures 2 and 3).

The autosite demonstrated a number of abnormalities. The skin overlying the skull was absent (focal cranial aplasia cutis), with the skull itself intact beneath this. The brain demonstrated no observable brain folds (gyri) and grooves (sulci) (lissenecephaly) (Figure 4). Most of the abdominal organs were exteriorized (eventeratio). Reflection of the skin demonstrated subcutaneous tissues that were diffusely gelatinous to watery, pale cream, with a large fluid-filled space in the subcutis of the dorsum just caudal to the ears (33 x $20 \times 10 \mathrm{~mm}$ ), which extended to a lesser extent along the entire dorsum (anasarca). The autosite lacked a sternum (sternal agenesis), although the thoracic cavity was separated from the parasite by thin intact pleura that formed a separate cavity. The heart was laterally displaced to the left side of the thoracic cavity, apparently due to the position of the parasitic puppy, and demonstrated no obvious gross abnormalities. Attached to the jejunum of the autosite, approximately mid-way along its length (Figure 5) was an extra portion of intestine that extended from the parasitic puppy and formed a non-patent rectum (atresia rectum) within this puppy. This portion of intestine was nonpatent with the autosite jejunum. Other abnormalities demonstrated by the autosite included cleft palate (palatoschisis), abnormal rotation of the liver 90 degrees anticlockwise (when viewed from a caudal direction) with two extra lobes of liver caudal to and with apparent vascular links with the rest of the lobes, and lack of omentum.

The partly-formed parasitic twin consisted of two formed hind limbs with four digits and claws attached to a rump without a tail. The rest of the parasite consisted of two, well-formed forelimbs, which formed a conjoined band across the top of the parasitic puppy's body, just ventral to the mandibles of the autosite. Additional findings on the parasitic puppy were a nonpatent vulva, absent genital tract and rectal and anal atresia. A single kidney and an associated small soft tissue structure that appeared grossly to be an adrenal gland were present within the parasite.

\section{Histology}

Selected tissue samples were taken for histological evaluation to confirm the gross findings. All tissue samples were fixed in $10 \%$ formal saline and embedded in paraffin wax. Eight-micron sections of paraffin embedded specimens were stained with hematoxylin and eosin. Histology of samples taken from the autosite heart, lungs, liver, kidney, spleen and small intestine and from the parasite small intestine and kidney appeared to be normal. The soft tissue structure adjacent to the kidney within the parasite appeared consistent with an adrenal gland.

In addition, sections of this soft tissue structure underwent immunohistochemistry using neuroendocrine markers, synaptophysin and chromogranin A. This confirmed the presence of neuroendocrine cells within the medulla of the gland (Polyclonal Rabbit AntiHuman Chromogranin A used at 1:500 and Polyclonal Rabbit Anti-Human Synaptophysin used at 1:50, Dako, Real Carpinteria, California, USA), also consistent with an adrenal gland.

\section{DISCUSSION}

A review of the medical literature of epigastric heteropagus twinning revealed that although most conjoined twins are female, most of the reported epigastric heteropagus twins are male (23/28) (Bhansali et al., 2005). In addition, the autosite may demonstrate cardiac abnormalities, such as patent ductus arteriosus, atrial and ventricular septal defects $(8 / 28)$ (Bhansali et al., 2005). There are no reported cases describing bony bridging between the autosite and parasite (Hwang et al., 1996) and bowel connection between parasite and autosite is extremely unusual (one reported case of Meckel's diverticulum attachment) (Nasta et al., 1986). In a further case, a 17-yearold boy had a duplicated bowel removed, which was 


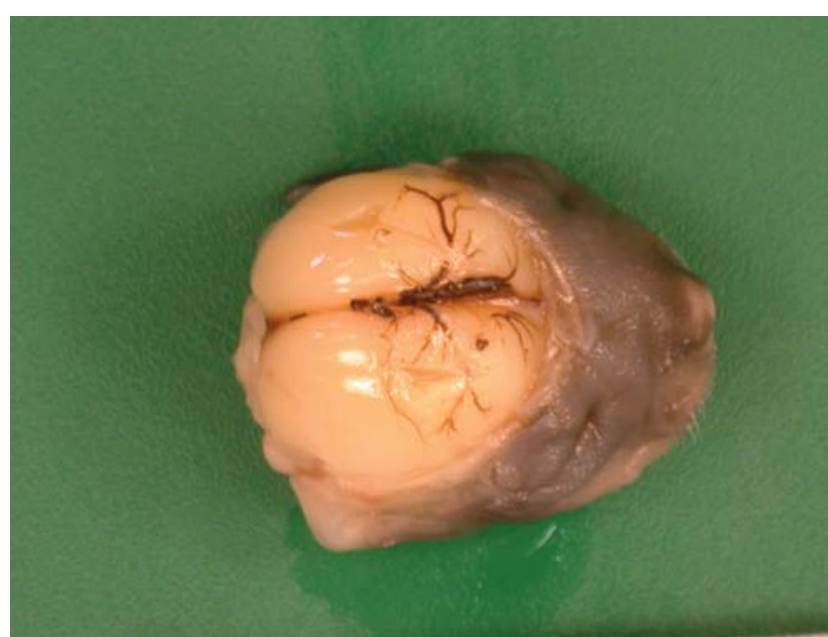

Figure 4. The head of the autosite with part of the cranium removed to show the brain which demonstrates lissencephaly.

believed to be remnants of an incomplete parasite twin (George et al., 2006).

In the Chihuahua puppy described in the present case, autosite and parasite were both female. The autosite heart was macroscopically within normal limits. Gross and radiological examinations revealed no bony bridges between autosite and parasite. However, there was a bowel connection, albeit non-patent, with the mid jejunum of the autosite to the non-patent intestine within the parasite.

Within the parasite, a single kidney and adrenal gland were demonstrated grossly and histologically. The two extra liver lobes could have arisen from the autosite or parasite in that they were adjacent to the other liver lobes, unlike the kidney, which was clearly within the torso of the parasite.

In addition, the autosite demonstrated other congenital abnormalities, including gastroschisis, anasarca, lissencephaly, palatoschisis, sternum agenesis and focal cranial aplasia cutis.

To the authors' knowledge, this is only the third reported case of heteropagus conjoined twinning in the dog and the first reported case of canine epigastric heteropagus twinning. In addition, there appear to be no reports in the veterinary literature noting an association with conjoined twinning in the dog with focal cranial aplasia cutis, eventeratio, lissencephaly, palatoschisis and anasarca.

However, these low figures can be biased as the search for similar cases in the literature is hampered by the lack of a uniform nomenclature to classify the different types of conjoined twinning. The most commonly used term today to indicate asymmetric conjoined twins is 'heteropagus', as opposed to 'diplopagus', which encompasses all forms of symmetric Siamese twins (Abubakar et al., 2011). Unfortunately, both are rather broad terms, covering a wide variety of anomalies. Furthermore, and specifically referring to cases of conjoined twinning in domestic animals, neither term is recognized by the official Nomina Embryologica Vet-

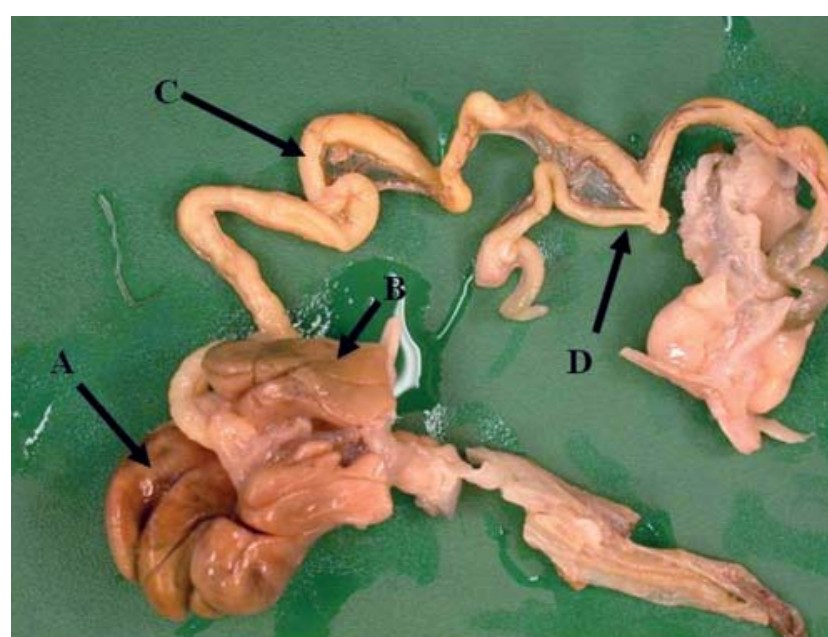

Figure 5. Exteriorized abdominal cavity contents from the autosite demonstrating the normal liver lobes(A), two extra liver lobes $(B)$, jejunum $(C)$ and the attached intestine from the parasite (D).

erinaria (N.E.V., 2006). Its terminology is organized in hierarchically nested lists as illustrated in Table 1. Although this stepwise approach allows a clear and more profound subdivision in this matter, it is impractical in medical conversations and more colloquial communications, in which a short but specific term is preferred.

A most exhaustive list of definitions and descriptions of congenital malformations, each provided with a single specific name, can be found in the magnum opus of the French zoologist Isidore Geoffroy SaintHilaire (1836). The terminology provided by Geoffroy Saint-Hilaire (1836) to classify monstrosities (defined as individuals with an abnormal external configuration) is to a certain extent still popular in the French and Spanish literature. It has not found its way into official nomenclature, as the N.E.V. (2006) prefers organ specific terms, whilst the classification and nomenclature by Geoffroy Saint-Hilaire (1836) are rather based on the gross morphological appearance of the affected body region as a whole. However, his classification of conjoined twins, which was further elaborated and illustrated by Lesbre (1927), is worthy of consideration for official adoption, as the used terminology is far more precise and more practical in daily use than the N.E.V. nomenclature.

Symmetric and asymmetric conjoined twins are respectively indicated by the prefix 'terato-' (e.g. teratopagus) and 'hetero-' (e.g. heteropagus). The suffix -pagus, which is the Latin form of the ancient Greek term $\pi$ óyos (= "that what is fixed"), refers to the joining of two complete individuals, i.e. both having an occiput and a complete vertebral column. In case only the cranial part of an individual is duplicated (the socalled Y-shaped conjoined twins) the suffix -pagus is replaced by '-(di)dymos', derived from the ancient

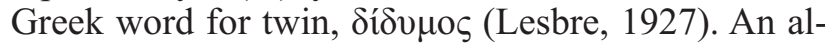
ternative to describe a teratodym individual is ' $\mathrm{du}$ plicitas anterior', or by using the prefix 'di-', followed by the specific term for the body region that is duplicated, e.g. 'diprosopia' (double face) (Luerssen, 1986). 
These alternatives, which feature in the official N.E.V. (2006) are however only to be used in symmetric conjoined twinning.

In the opposite case of caudal duplication (lambdoid or $\lambda$-shaped individuals), Geoffroy Saint-Hilaire (1836) and Lesbre (1927) preferred the suffix '-adelphos' $(\alpha \delta \varepsilon \dot{\lambda} \varphi \varsigma \varsigma=$ close relative, having a blood relation) e.g. teratadelphos. Again, alternatives to describe such symmetric twins are dipygus or duplicitas posterior (N.E.V., 2006), whilst a proper official term for asymmetric caudal duplication is lacking. Interestingly, Lesbre (1927) defined heteradelphia as asymmetric conjoined twinning in which the parasite is attached in the umbilical region of the autosite and lacks both a head and tail. Although variable in appearance and organization, in almost all cases, the parasite does not possess any part of the thoracic skeleton nor a vertebral column, hence explaining the lack of a tail (Lesbre, 1927). This description entirely matches the case presented in this manuscript.

On the other hand, similar cases as illustrated in ancient German literature are preferentially indicated by the term 'epigastrius' (Schwalbe, 1907). A literature search in the PubMed and Web of Knowledge online databases (accessed November 2011) could only reveal four different papers in which the term 'epigastrius' is used, which is equal to the number of hits for 'heteradelph*' in a period between 1864 (Acton, 1864) and 2011. Although a nomenclature to clearly specify asymmetric conjoined twins is available for already 175 years, this terminology is poorly distributed in scientific literature, not adopted in official terminology nor superseded by equivalent but more commonly-used terms.

The present case report illustrates that asymmetric conjoined twinning is not restricted to hand-drawn sketches in old textbooks, but still can be encountered in daily practice today. To allow a proper search for, scientific analysis of, and easy comparison between similar cases, a correct, practical and widely recognized uniform terminology remains a prerequisite.

\section{REFERENCES}

Abubakar A.M., Ahidjo A., Chinda J.Y., Tahir C., Abubakar S., Adamu S.A., Pindiga U.H. (2011). The epigastric heteropagus conjoined twins. Journal of Pediatric Surgery 46, 417-420.

Acton W. (1864). An account of a case of partial double monstrosity (ischiopage symelien of Geoffroy Saint-Hilaire, heteradelphia of Vrolik). Medico-Chirurgical Transactions 29, 103-106.3.

Arthur G.H. (1956). Conjoined and identical twins. Veterinary Record 68, 389.

Bhansali M., Sharma D.B., Raina V.K. (2005). Epigastric heteropagus twins: 3 case reports with review of the literature. Journal of Pediatric Surgery 40, 1204-1208.

Blood D.C., Studdert V.P. (1999). Saunders Comprehensive Veterinary Dictionary, $2^{\text {nd }}$ Ed., WB Saunders, Philadelphia. p. 405.

Charda R., Bagga D., Dhar A., Mohta A., Malhotra C.J.,
Taneja S.B. (1993). Epigastric heteropagus. Journal of Pediatric Surgery 28, 723-727.

Cury E.K., Schraibman V. (2001): Epigastric heteropagus twinning. Journal of Pediatric Surgery 36, Ell.

Dennis S.M. (1975). Embryonic duplications in sheep. Australian Veterinary Journal 51, 83-87.

Geoffroy Saint-Hilaire I. (1836). Histoire générale et particulière des anomalies de l'organisation chez l'homme et les animaux: ouvrage comprenant des recherches sur les caractères, la classification, l'influence physiologique et pathologique, les rapports généraux, les lois et les causes des monstruosités, des variétés et vices de conformation, ou traité de tératologie, Tome II. J.-B. Baillière, Paris, p. 536-566.

George A.T., Varkey S., Kalam A., Surendran N. (2006). Left over bowels: a unique complication in a surviving twin. Postgraduate Medical Journal 80, 736-737.

Gupta D.K., Lall A., Bajpai M. (2001). Epigastric heteropagus twins - a report of four cases. Pediatric Surgery International 17, 481-482.

Hong C.C., Ediger R.D., Djurickovic S. (1977). Conjoined twins and opocephaly in guinea pigs: 4 cases of congenital malformation. Laboratory Animals 11, 189-191.

Hwang E.H., Han S.J., Lee J.S., Lee M.K. (1996). An unusual case of monozygotic epigastric heteropagus twinning. Journal of Pediatric Surgery 31, 1457-1460.

Kanamori Y., Tomonaga T., Sugiyama M., Hashizume K., Goishi K., Haga N. (2006). Bizarre presentation of epigastric heteropagus: report of a case. Surgery Today 36, 914-918.

Karnak I., Ciftci A.O., Büyükpamukçu N. (1999). Epigastric heteropagus: a case report with review of the literature. European Journal of Pediatric Surgery 9, 347 - 50.

Kompanje E.J.O. (2005). Two cases of asymmetrical conjoined twins in wild mammals from the Netherlands. Deinsea 11, 139-145.

Lesbre F.-X. (1927). Traité de Tératologie de l'Homme et des Animaux Domestiques. Vigot frères, Paris, p. 207-284.

Logrono R., Garcia-Lithgow C., Harris C., Kent M., Meisner L. (1997). Heteropagus conjoined twins due to fusion of two embryos: report and review. American Journal of Medical Genetics 73, 239-243.

Luerssen D. (1986). Partial dicephalia in a cat (duplicitas anterior, diprosopus) with triophthalmia. Kleintierpraxis 31, 179.

Mazullo G., Monteverde V., Macri F., Partanna S., Caracappa S. (2007). Incomplete caudal duplication in a puppy: gross and radiological observations. Journal of Small Animal Practice 48, 410-413.

McManus C.A., Partlow G.D., Fisher K.R. (1994). Conjoined twin piglets with duplicated cranial and caudal axes. Anatomical Record 239, 224-229.

Nasta R., Scribilia G., Corroa A., Iacono M. (1986). Surgical treatment of an asymmetric double monstrosity with oesophageal atresia, omphalocoele and interventricular defect. Journal of Paediatric Surgery 21, 60-62.

N.E.V. Nomina Embryologica Veterinaria (2006). $2^{\text {nd }}$ Ed. http://www.wava-amav.org/Downloads/nev_2006.pdf [accessed 23/08/2011]

Nottidge H.O., Omobowale T.O., Olepade J.O., Oladiran O.O., Ajala O.O. (2007). A case of craniothoracopagus (monocephalus thoracopagus tetrabrachius) in a dog. Anatomia, Histologia, Embryologia. 36, 179-181.

Otiangi-Owitis G.E., Oduo-Okele D., Kamau G.K., Makori N., Hendrickx A.G. (1997). Morphology of a six-legged 
goat with duplication of the intestinal, lower urinary and genital tracts. Anatomical Record 242, 432-438.

Ozcan C., Ergün O., Güçlü C., Tümüklü M., Alper H., Erdener A. (2000). An unusual case of epigastric heteropagus: parasite with a rudimentary heart. Journal of Pediatric Surgery 35, 1523-1525.

Potter E.L., Craig J.M. (1975). Pathology of the Fetus and Newborn. 3rd Ed., Chicago IC Yearbook, p. 220-237.

Ribeiro R.C., Maranhao R.F., Moron A.F., Leite M.T., Cordioli E., Hisaba W., Martins J.L. (2005). Unusual case of heteropagus twinning. Journal of Paediatric Surgery 40, E39-41.

Saha P.L., Dewan P.A. (1995). Late presentation of epigastric heteropagus. Pediatric Surgery International 10, 432433.

Schwalbe E. (1907). Die Morphologie der Missbildungen des Menschen und der Tiere, ein Lehrbuch für Morphologen, Physiologen, praktische Ärzte und Studierende, II. Teil: Die Doppelbildungen. Gustav Fisher, Jena, p. 346350 .
Seavers A.M. (2009). Monocephalus dipygus paraparagus: a suspected case of complete caudal duplication in a British Blue kitten. Journal of Feline Medicine and Surgery 11, 330-332.

Seebaransingh R.A., Adowa A.O., Gibbons I.R. (2006). Bovine epigastric heteropagus in Trinidad and Tobago: a case study. Veterinary Record 159, 49-50.

Selby L.A., Khalili A., Stewart R.W., Edmonds L.D., Marienfeld C.J. (1972). Pathology and epidemiology of conjoined twinning in swine. Teratology 8, 1-9.

Spencer R. (1992). Conjoined twins: theoretical embryologic basis. Teratology 45, 591-602.

Tongsin A., Niramis R., Rattanasuwan T. (2003). Epigastric heteropagus twins: a report of four cases. Journal of the Medical Association of Thailand. 86, Suppl 3, S605-609.

Tovar J.A. (2009). Pediatric Surgery: Diagnosis and Management. In: Puri P., Höllwarth M. (Editors). Springer, London, p. $647-658$. 